\title{
PURIFICATION AND BIOCHEMICAL CHARACTERIZATION OF AN EXTRACELLULAR LIPASE PRODUCED BY A NEW STRAIN OF Rhizopus sp.
}

\author{
Purificação e caracterização bioquímica de lipase extracelular produzida \\ por uma nova linhagem de Rhizopus sp.
}

\author{
Maria Gabriela Bello Koblitz' ${ }^{1}$, Gláucia Maria Pastore ${ }^{2}$
}

\begin{abstract}
The present study had as a goal to purify and characterize the lipolytic fraction secreted by a strain of Rhizopus sp. Only 3 steps of purification were necessary to achieve SDS-PAGE homogeneity. One band with $37.5 \mathrm{KDa}$ molecular mass and with $1446 \mathrm{U} /$ $\mathrm{mg}$ specific activity was obtained. The purified fraction presented 2 lipase isoforms; both showed optimum activity at $50^{\circ} \mathrm{C}$, and were stable between 6.5 and $7.5 \mathrm{pH}$ values and at temperatures below $50^{\circ} \mathrm{C}$ and also kept their activity in hexane. The lipase was inactivated by $\mathrm{Hg}^{+2}$ and by n-bromosuccinimide and activated by $\mathrm{Na}^{+}$.
\end{abstract}

Index terms: Lipase, Rhizopus sp., purification, biochemical characterization.

\section{RESUMO}

O presente trabalho teve por objetivo purificar e caracterizar a fração lipolítica secretada por uma linhagem de Rhizopus sp. Apenas 3 etapas de purificação foram necessárias para alcançar homogeneidade em eletroforese de proteína desnaturada. Uma única banda com massa molecular de 37,5 KDa e atividade específica de 1446U/mg foi obtida. A fração purificada apresentou 2 isoformas de lipase, ambas com temperatura ótima de atividade igual a $50^{\circ} \mathrm{C}$, mantiveram-se estáveis entre valores de $\mathrm{pH}$ entre 6,5 e 7,5 e a temperaturas inferiores a $50^{\circ} \mathrm{C}$ e mantiveram sua atividade na presença de hexano. A fração lipolítica foi inativada por $\mathrm{Hg}^{+} \mathrm{e}$ por $\mathrm{n}$ bromosuccinimida e ativada por $\mathrm{Na}^{+}$.

Termos para indexação: Lipase, Rhizopus sp., purificação, caracterização bioquímica.

\section{(Recebido para publicação em 19 de julho de 2005 e aprovado em 7 de fevereiro de 2006)}

\section{INTRODUCTION}

Lipases are enzymes belonging to the group of serine hydrolases (E.C. 3.1.1.3). Their natural substrates are triglycerides and their mode of action is similar to that of the esterases. However, their activity is considerably increased when they are located at the polar/non polar interface. The lipases are able to catalyze hydrolysis, esterification, transesterification and lactonization (intramolecular esterification) (JAEGER \& EGGERT, 2002). This flexibility, associated with the possibility of different substrate specificity among the different lipases, gives these enzymes an enormous potential for applications (GANDHI et al., 2000). Among the various industrial applications of lipases, two of them have special interest flavor ester synthesis for use in the food and pharmaceutical industries (MACEDO et al., 2004; MELLO et al., 2005) and the biodiesel production (PARK \& PIZARRO, 2003). Besides their industrial application possibilities, the lipases are linked to the deterioration of some products, mainly dairy products and oils, and the identification and study of their mode of action may aid in the solution of these problems (HIOL et al., 2000).
Lipases can be found in animal and vegetable cells and they can also be produced by microorganisms. From the industrial point of view these are considered very important, due to their great production potential on a large scale and to the capacity of deterioration of microorganisms (KIRK et al., 2002). Fungal lipases are among the most important commercial enzymes and the Rhizopus species are well-known lipolytic microorganisms (D'ANNIBALE et al., 2005; YANG et al., 2005). This work reports on the isolation, characterization, and some biochemical aspects of the lipase secreted by Rhizopus sp.

\section{MATERIAL AND METHODS}

\section{Microorganism and Culture conditions}

$1 \mathrm{~mL}$ of spore suspension, from a culture in PDA (potato, dextose, agar) medium after 72 hours incubation, was inoculated into $500 \mathrm{~mL}$ Erlenmeyer flasks containing $20 \mathrm{~g}$ of wheat bran and water $(60: 40 \mathrm{w} / \mathrm{w})$. These flasks were incubated at $30^{\circ} \mathrm{C}$ for 120 hours and the lipase produced was extracted with distilled water, followed by filtration.

${ }^{1}$ Professora Adjunta da Faculdade de Engenharia de Alimentos - Universidade Estadual de Feira de Santana/DTEC - Km 03, BR116 Norte Campus Universitário s/no - 44031-460 - mkoblitz@gmail.com

${ }^{2}$ Professora Adjunta da Faculdade de Engenharia de Alimentos - Universidade Estadual de Campinas/FEA/DCA-glaupast@fea.unicamp.br 


\section{Enzyme Purification (BEISSON et al., 2000).}

Ammonium sulfate was added to the culture broth up to $70 \%$ saturation, the solution was allowed to rest overnight at $4^{\circ} \mathrm{C}$ and then centrifuged at $10,000 \times \mathrm{g}$ for 10 minutes.The resulting precipitate was dialyzed against distilled water for 48 hours at $4^{\circ} \mathrm{C}$. The product obtained was freeze dried and maintained at $-10^{\circ} \mathrm{C}$. This freeze dried enzyme preparation was dissolved in sodium acetate buffer $(\mathrm{pH}=5.6 ; 50 \mathrm{mmol} / \mathrm{L})$ to a concentration of $50 \mathrm{mg} / \mathrm{mL}$, centrifuged at 10,000 $\mathrm{x} g$ for 10 minutes and filtrate through acetate membrane with pore of $0.22 \mathrm{~mm}$.

A pre-packed Q Sepharose fast flow column of 5 $\mathrm{mL}$ of internal volume, equilibrated with sodium acetate buffer $(\mathrm{pH}=5.6 ; 50 \mathrm{mmol} / \mathrm{L})$, was employed for the anionic exchange chromatographic step. The injection consisted of $1 \mathrm{~mL}$ of crude enzyme and elution was achieved using a non-linear $\mathrm{NaCl}$ gradient, with a final concentration of 1 $\mathrm{mol} / \mathrm{L}$ of the salt and a flow rate of $5 \mathrm{~mL} / \mathrm{min}$. Fractions of 5 $\mathrm{mL}$ were collected. Active fractions were pooled, dialyzed against water and freeze-dried.

This partially purified lipolytic fraction was dissolved in sodium acetate buffer $(\mathrm{pH}=5.6 ; 50 \mathrm{mmol} / \mathrm{L})$ containing $0.15 \mathrm{~mol} / \mathrm{L} \mathrm{NaCl}$ to a concentration of $20 \mathrm{mg} / \mathrm{mL}$ and filtrated through acetate membrane (pore: $0.22 \mathrm{~mm}$ ). 1 $\mathrm{mL}$ of this preparation was loaded to a pre-packed Sephacryl S200 column ( 2 x $60 \mathrm{~cm}$, void volume of $120 \mathrm{~mL})$ for the gel filtration chromatographic step. The eluton flow rate was $0.3 \mathrm{~mL} / \mathrm{min}$ and fractions of $2.4 \mathrm{~mL}$ were collected. A FPLC equipment (Amersham Pharmacia Biotech) was employed in all chromatographic steps.

For determination of molecular mass by gel filtration the calibration curve was prepared using standard proteins. Void volume was determined using blue dextran. Molecular mass of the lipase from Rhizopus sp. was calculated from the regression curve where the log of the molecular mass of each standard was plotted against the ratio of the elution volumes of the standards and the void volume $\left(\mathrm{V}_{\mathrm{e}} / \mathrm{V}_{0}\right)$.

\section{Determination of Protein}

Protein was estimated colorimetrically according to Lowry et al. (1951) using bovine serum albumin (BSA) as standard. In the chromatography separation, the protein concentration in the fraction was routinely estimated by measuring the absorbance at $280 \mathrm{~nm}$.

\section{Lipase detection - assay of esterase activity:}

Enzyme activity was assayed spectrophotometrically using p-nitrophenyllaurate (p-NPL) as substrate, according to Lin et al. (1995). Incubations were performed at $40^{\circ} \mathrm{C}$ for
15 minutes and the release of p-nitrophenol was measured at $410 \mathrm{~nm}$ using a DU-640 spectrophotometer (Beckman Coulter). One enzyme unit corresponded to the release of one $\mathrm{mmol} / \mathrm{L}$ of $\mathrm{p}$-nitrophenol per minute under the assay conditions.

\section{Analytical gel electropheresis}

SDS-PAGE was run on a Bio-Rad Mini-Protean II Dual Slab Cell, following the manufacturer's instructions. Analyses according to Laemmli (1970). The gels were stained with Coomassie Brillant Blue R-250.

\section{Effect of $\mathrm{pH}$ values and of the temperature on the activity and stability of the lipase}

The optimal temperature for the hydrolysis of p-nitrophenyllaurate was determined by measuring the rate of reaction at temperatures ranging from 30 to $70^{\circ} \mathrm{C}$ under standard assay conditions, at $\mathrm{pH}$ 5.6. For studying thermal stability, the enzyme was incubated at temperatures ranging from 30 to $70^{\circ} \mathrm{C}$ for 1 hour. Aliquots were taken after incubation and the residual activity determined. The optimal $\mathrm{pH}$ for enzyme activity was determined by measuring $\mathrm{p}$-nitrophenyllaurate hydrolysis at $\mathrm{pH}$ values ranging from 3.6 to 9.0 in various buffers, at $40^{\circ} \mathrm{C}$. The effect of $\mathrm{pH}$ on lipase stability was studied by measuring residual activity at $\mathrm{pH} 5.6$, after 24 hours incubation at $\mathrm{pH}$ values ranging from 3.6 to 9.0 , at $25^{\circ} \mathrm{C}$.

\section{Isoeletric focusing}

Isoeletric point determination was run on IPG (immobilized $\mathrm{pH}$ gradient) strips with non-linear separation range of 3-10 (Amersham Biosciences), according to manufacturer's instructions. Proteins were detected using standard Coomassie Blue staining and isoeletric point was determined according to a calibrating curve supplied by the manufacturer.

\section{Analytical RP-HPLC of purified lipase}

The purified lipase preparation was analyzed for homogeneity by RP-HPLC under the following conditions: column - Bondapack (preparative scale; 7.8x300mm); flow rate $1 \mathrm{~mL} / \mathrm{min}$; initial solution (sol A): $0.1 \%$ TFA in water, elution: linear gradient with solution B $(60 \%$ acetonitrile in sol. A); total volume: $50 \mathrm{~mL}$. Protein was detected at $280 \mathrm{~nm}$.

\section{$\mathrm{Km}$ and Vmax determination}

Michaelis-Menten constants for the lipase substrate p-NPL were determined by incubating the purified enzyme with concentrations of the substrate ranging from 0.1 to 3.0 
$\mathrm{mmol} / \mathrm{L}$. The constant values were calculated according to the Lineweaver-Burk graphic method.

Determination of lipase activity and specificity (PALEKAR et al., 2000).

Lipolytic activity on different triacylglycerols was determined titrimetrically using $10 \mathrm{mmol} / \mathrm{L} \mathrm{KOH}$ as titrant. The reaction medium contained $0.1 \mathrm{~g}$ tributyrin, tricaprylin, trilaurin, triolein, or tristearin as synthetic substrates and coconut fat, olive oil or cow's milk cream ( $25 \%$ fat) as natural substrates, dispersed by stirring in $1 \mathrm{~mL}$ of $50 \mathrm{mmol} / \mathrm{L}$ sodium acetate buffer $\mathrm{pH}=5$.6. Hydrolysis was measured at $50^{\circ} \mathrm{C}$ and $150 \mathrm{rpm}$ for 60 minutes. The reaction was initiated by the addition of enzyme and terminated by the addition of $15 \mathrm{~mL}$ of acetone/ethanol (1:1 v/v). One enzyme unit corresponded to the release of one mmole of fatty acid per minute under the assay conditions.

\section{Stability in organic solvents}

$1 \mathrm{mg}$ of the purified enzyme was incubated in the presence of $1 \mathrm{~mL}$ of different organic solvents for 1 hour, under refrigeration. Control was kept in buffer solution $(\mathrm{pH}=7.0,0.05 \mathrm{~mol} / \mathrm{L})$. After this time the solvents were evaporated with Nitrogen and the enzyme dissolved in buffer solution ( $\mathrm{pH}=7.0,0.05 \mathrm{~mol} / \mathrm{L})$. Residual activity was measured by the standard assay system.

\section{The effect of inhibitors/effectors}

The purified lipase was incubated with various compounds $(1 \mathrm{mmol} / \mathrm{L})$ at $30^{\circ} \mathrm{C}$ for 1 hour. The remaining activity was measured using the standard assay system.

\section{RESULTS AND DISCUSSION}

\section{Enzyme production and purification}

Hiol et al. (2000) studied a lipase from Rhizopus oryzae strain and found the maximal enzyme concentration corresponded to $120 \mathrm{U} / \mathrm{mL}$ lipolytic activity. In a previous work of the same research group (HIOL et al., 1999) a strain of Mucor hiemalis produced less than $100 \mathrm{U} / \mathrm{mL}$ and the enzyme extraction involved a defatting step with hexane. The Penicillium camembertii strain studied by Tan et al. (2004) could only produce $80 \mathrm{U} / \mathrm{mL}$, even after optimization of the culture medium. The strain of Rhizopus sp. reported in the present work generated $579.4 \mathrm{U} / \mathrm{mL}$ of lipolytic activity in the extraction broth. Therefore the strain in question was considered to be a very good lipase secretor. It must also be taken into account that the solid fermentation medium is very inexpensive (by product of the flour industry) and that the enzyme extraction is very simple.

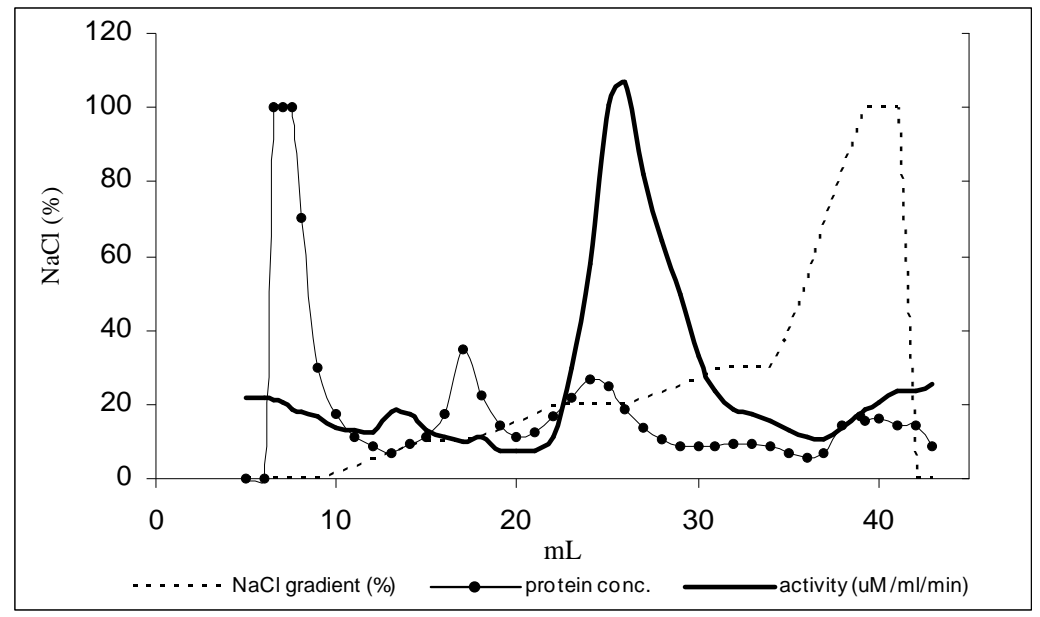

FIGURE 1 - Chromatography of lipase from Rhizopus sp. on Q Sepharose.

Ciênc. agrotec., Lavras, v. 30, n. 3, p. 494-502, maio/jun., 2006 


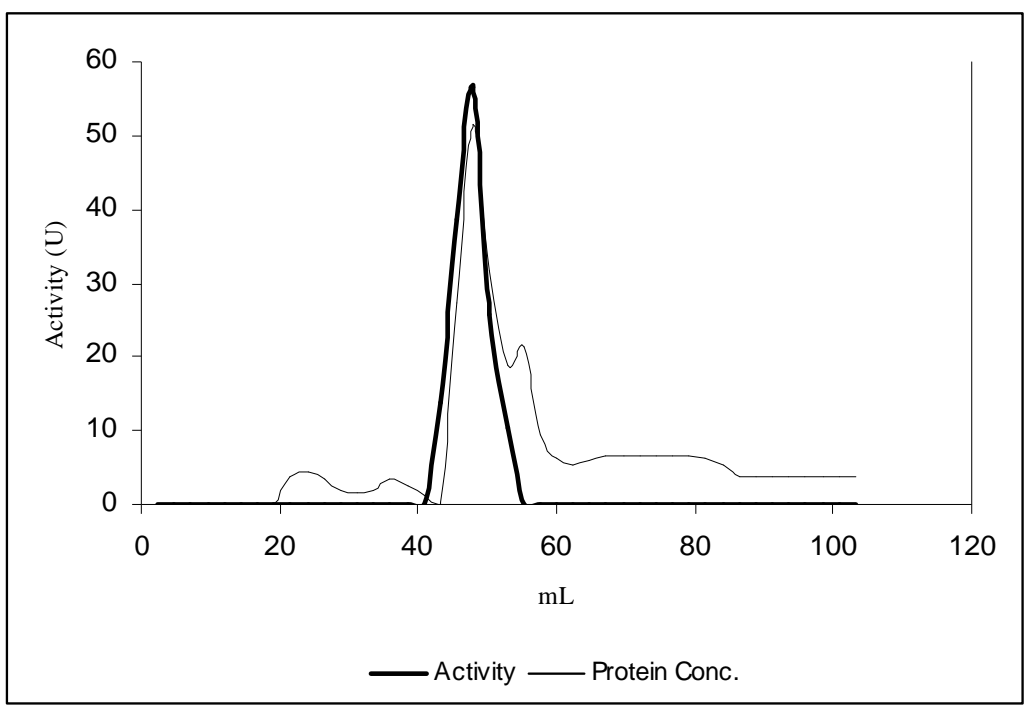

FIGURE 2-Chromatography of lipase from Rhizopus sp on Sephacryl S200.

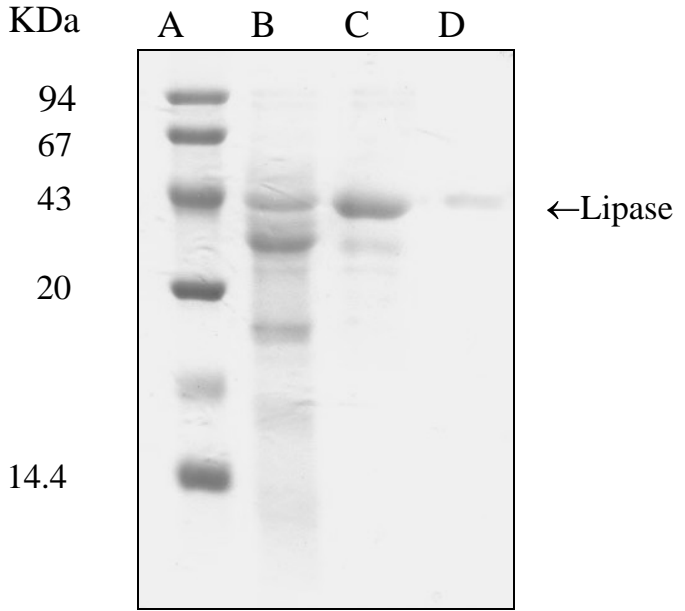

FIGURE 3 -SDS-page of Rhizopus sp. lipase at various stages of purification. Lane A: molecular weight markers; Lane B: crude extract; Lane C: Q Sepharose; Lane D: Sephacryl S200.

As shown in Figure 3, upon analytical SDS-PAGE, the purified enzyme, appeared as a single band with molecular mass around $40 \mathrm{KDa}$. Upon gel filtration, a single peak of lipase activity was eluted and corresponded to a protein of molecular mass of $37.5 \mathrm{KDa}$ (Figure 2, calculations not shown). These results indicate that the enzyme is a monomer. Other fungal lipases present molecular masses around the same value, e.g. Aspergillus niger $35.5 \mathrm{KDa}$ (NAMBOODIRI \& CHATTOPADHYAYA, 2000); Ophiostoma piceae $37 \mathrm{KDa}$ (GAO \& BREUIL, 1998); Mucor hiemalis $49 \mathrm{KDa}$ (HIOL et al., 1999).

Only three purification steps were required to reach SDS-PAGE homogeneity. The purified lipase showed specific activity of $1446 \mathrm{U} / \mathrm{mg}$, with a 9.7 -fold purification. The final specific activity obtained here was high compared to some fungal lipases, e.g. $63 \mathrm{U} / \mathrm{mg}$ for Pythium ultimatum lipase (MOZAFFAR \& WEETE, 1993), $189 \mathrm{U} / \mathrm{mg}$ for $R$. oryzae and $11.1 \mathrm{U} / \mathrm{mg}$ for $R$. rhizopodiformis lipases (RAZAK et al., 1997), and although purification factor and yield (Table 1) seem rather low, they are similar to other published data (KERMASHA et al., 1998; RAZAK et al., 1997).

In contrast to SDS-PAGE, where only one protein band was resolved on the gel, two protein bands at $\mathrm{pI}$ values 4.3 (minor) and 4.6 (major) were observed after IEF (Figure 4). Since both bands appeared to be lipolytically active (see Figure 6 and discussion below) the two bands probably represent isoforms of the lipase. The presence of multiple lipases was also reported for Pythium ultimatum lipase (MOZAFFAR \& WEETE, 1993), and for Ophistoma piceae lipase (GAO \& BREUIL, 1998).

The presence of two major proteins in the sample was confirmed by analytical reversed-phase HPLC. The little difference between their retention times might indicate a strong similarity of both lipases. 
TABLE 1 - Summary of the purification of lipase from Rhizopus sp.

\begin{tabular}{lccccc}
\hline Step & $\begin{array}{c}\text { Total activity } \\
(\mathbf{U})\end{array}$ & $\begin{array}{c}\text { Total protein } \\
(\mathbf{m g})\end{array}$ & $\begin{array}{c}\text { Specific activity } \\
(\mathbf{U} / \mathbf{m g})\end{array}$ & $\begin{array}{c}\text { Purification } \\
\text { fold }\end{array}$ & $\begin{array}{c}\text { Yield } \\
(\%)\end{array}$ \\
\hline Crude extract & 1245710.0 & 8342.0 & 149.3 & 1.0 & 100.0 \\
Ammonium sulfate & & & & & \\
fraction & 619019.5 & 3010.2 & 205.6 & 1.4 & 49.7 \\
Q Sepharose & 907892.0 & 684.4 & 1326.6 & 8.9 & 72.9 \\
Sephacryl & 3071.3 & 2.1 & 1446.0 & 9.7 & 0.25 \\
\hline
\end{tabular}

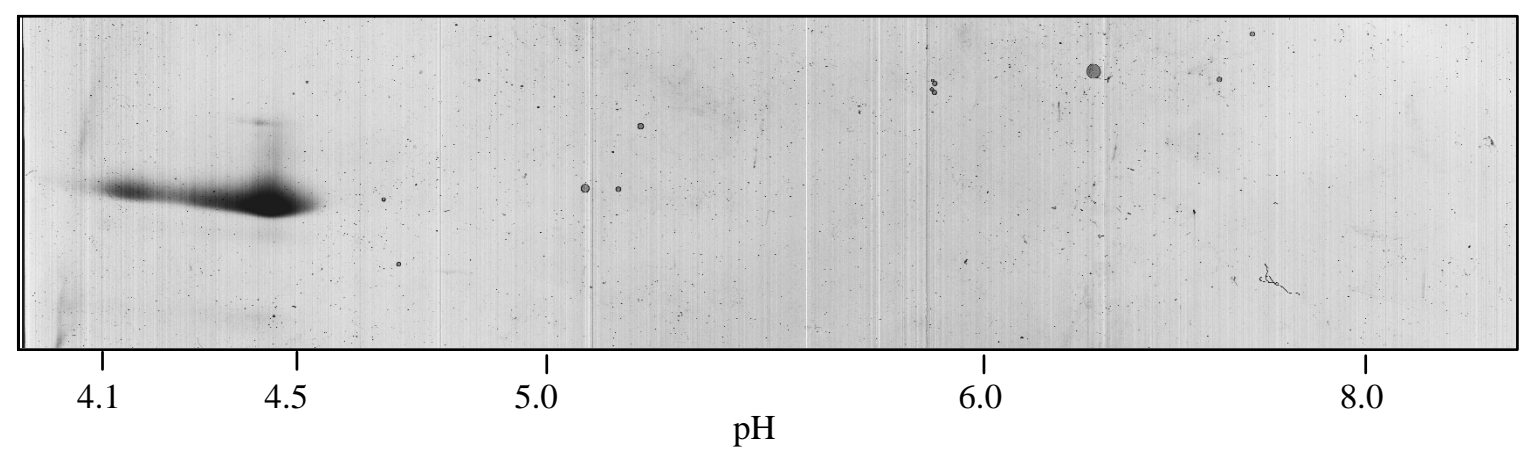

FIGURE 4 - Isoeletric point of both isoenzymes from Rhizopus sp. lipolytic fraction.

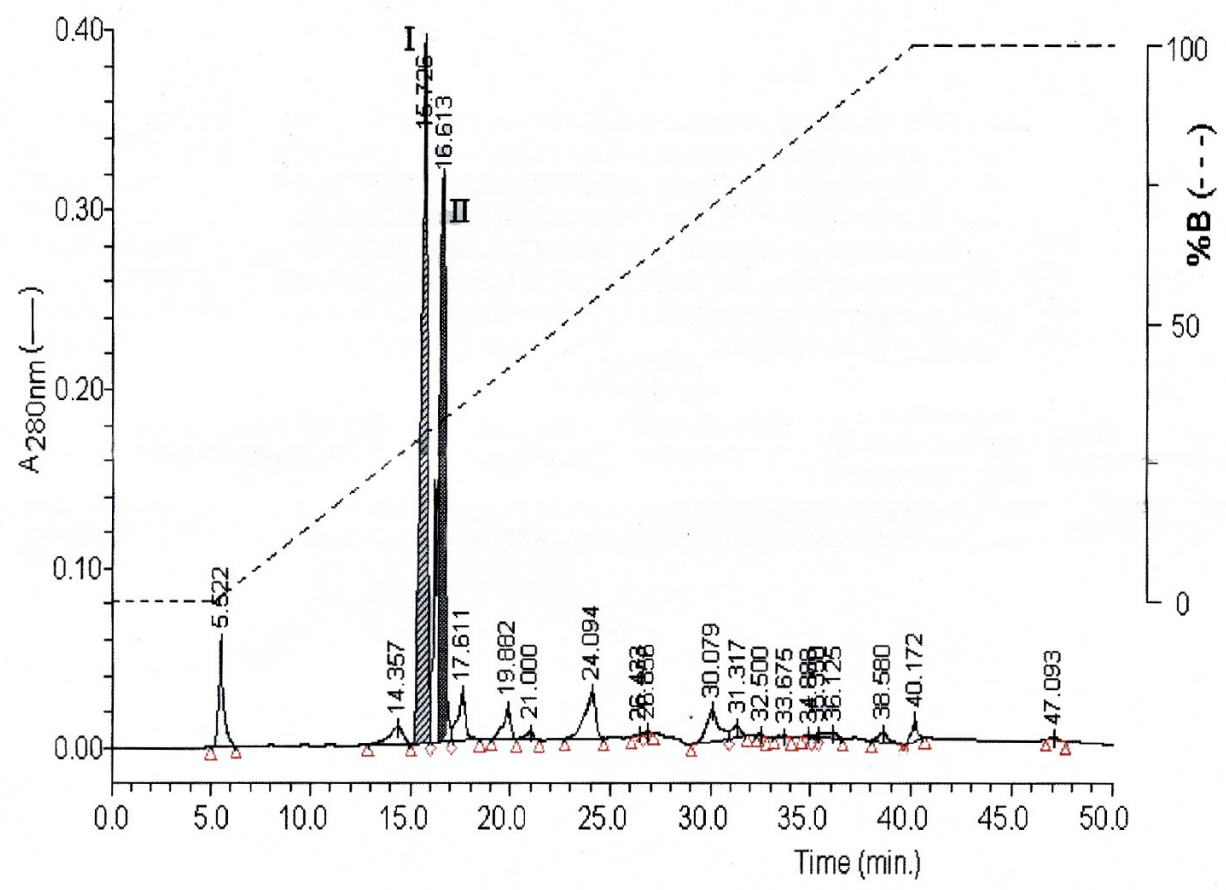

FIGURE 5 - HPLC chromatogram for the purified lipolyitc fraction produced by Rhizopus sp.

Ciênc. agrotec., Lavras, v. 30, n. 3, p. 494-502, maio/jun., 2006 


\section{Biochemical Characterization}

The optimal temperature for the lipase activity was $50^{\circ} \mathrm{C}$ (Fig.7). Aspergillus carneus lipase showed optimum activity at $37^{\circ} \mathrm{C}$ (SAXENA et al., 2003) and according to Razak et al. (1997) very few fungal lipases exhibit temperature optima above $40^{\circ} \mathrm{C}$, thus the extra cellular lipase from Rhizopus sp. may have potential in high temperature reactions. According to Kambourova et al. (2003), the interest in running bioprocesses at high temperatures lies in the favorable changes in most physical properties of fats in elevated temperatures and in the stability of thermostable lipases in organic solvents. The enzyme was stable at temperatures below $50^{\circ} \mathrm{C}$ keeping at least $40 \%$ of its activity after $1 \mathrm{~h}$ treatment.

The purified lipase showed two different optima $\mathrm{pH}$ values: 5.5 and 7.0. This may indicate that both proteins revealed by IEF and RP-HPLC have lipolytic activity, each one presenting an optimal $\mathrm{pH}$ value. Since the isoenzymes seem to be very similar (same molecular mass, same optimal temperature and similar hydrophobicity) it would be very useful to protein engineering to verify their structural differences. The lipase was stable over a $\mathrm{pH}$ range of 6.5-7.5.

The kinetic studies of the purified enzyme showed a $\mathrm{K}_{\mathrm{m}}$ value of $2.4 \mathrm{mmol} / \mathrm{L}$ and $\mathrm{a}_{\text {max }}$ value of $277.8 \mathrm{U}$ for the synthetic substrate $p$-NPL (data not shown).

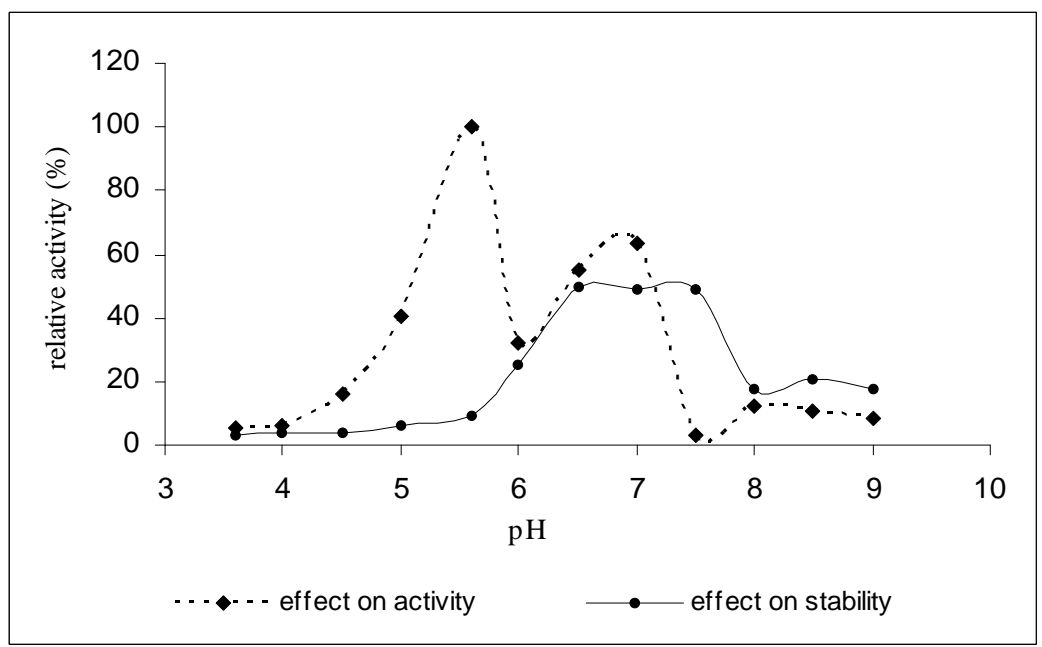

FIGURE 6-Effect of pH on the activity and stability of lipase from Rhizopus sp.

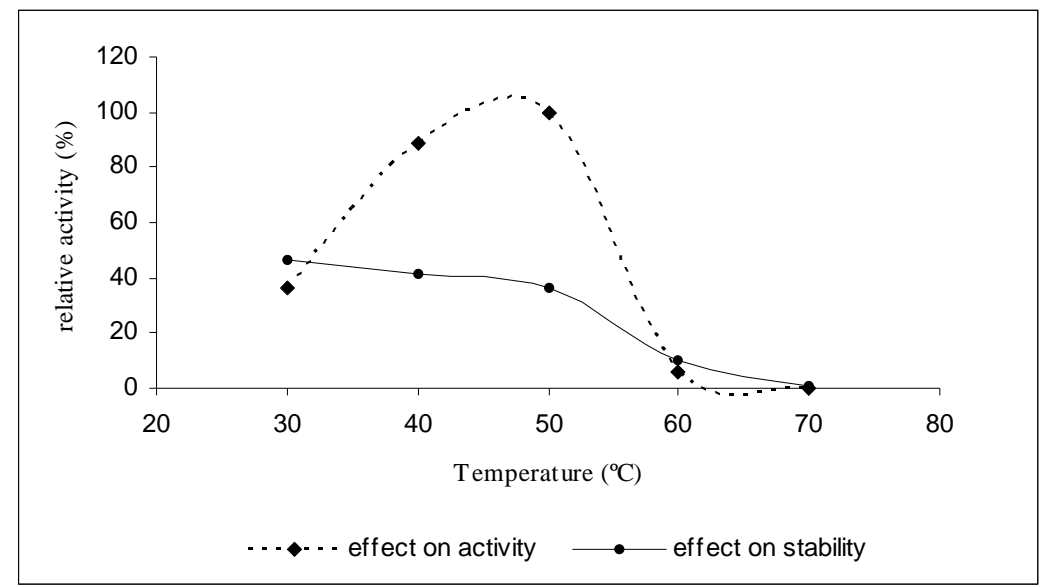

FIGURE 7 -Effect of temperature on the activity and stability of lipase from Rhizopus sp. 
The purified lipase hydrolyzed all triacylglycerol tested, and highest activity was obtained with tributyrin. Activity decreased with the increase of the chain length although even tristearin could be hydrolyzed by the enzyme. Hydrolysis of natural fats and oils followed the same pattern. According to Gao \& Breuil (1998) this substrate specificity is shared by the majority of the fungal lipases. It is interesting to notice, however, that this same Rhizopus sp. lipase showed a different substrate specificity when the esterification of 2-octanol with serveral fatty acids was tested. In this case activity increased with increasing chain lenght (from 4C to 8-12C) (MACEDO et al., 2003).

$\mathrm{Hg}^{+2}$ strongly inhibited the lipase activity and $\mathrm{Na}^{+1}$ lightly enhanced it (data not shown). This behavior was also observed for the Aspergillus carneus lipase (SAXENA et al., 2003). Other compounds did not affect the activity of the enzyme. The exception was n-bromosuccinimide which, according to Voet \& Voet (1995) inhibits enzymes that contain histidine, tryptophan and / or tyrosine residues in the active site.

The stability of lipase in organic solvents offers advantages for enzyme precipitation and synthesis. As shown in Table 2, the Rhizopus sp. lipase had good stability in hexane but was highly denatured in hydrophilic solvents, especially methanol. This behaviour was also observed by Hiol et al. $(1999,2000)$ for M. hiemalis and $R$. oryzae lipases.

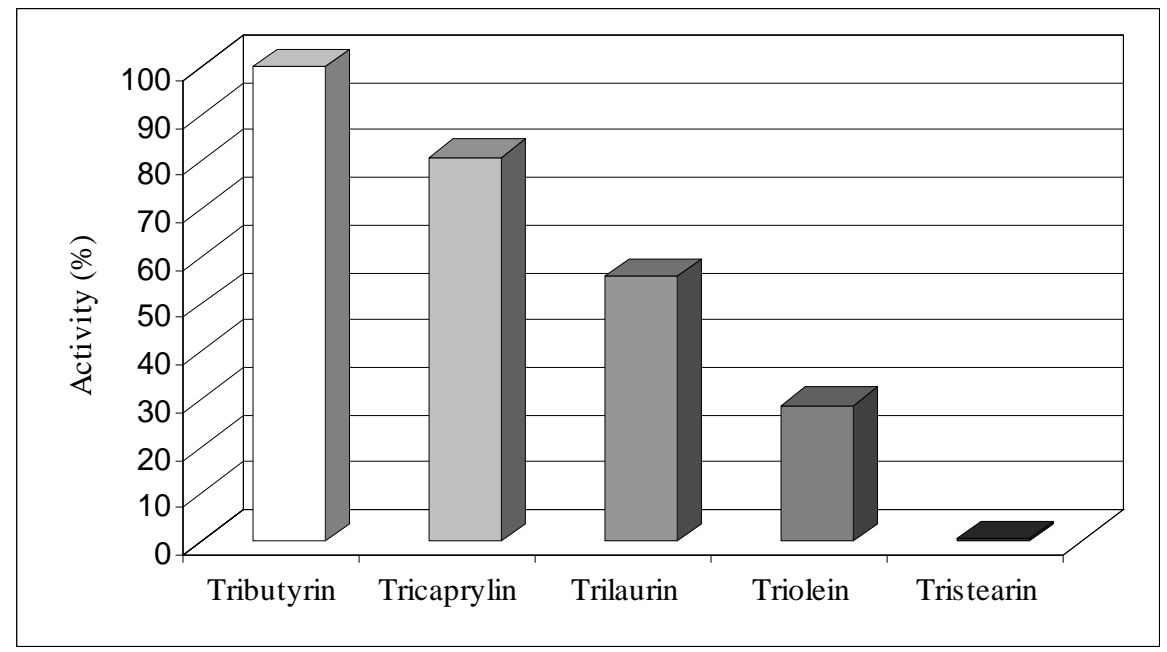

FIGURE 8-Activity of Rhizopus sp. lipase against different synthetic triacylglycerols.

TABLE 2 - Stability of the purified lipase in different organic solvents.

\begin{tabular}{lc}
\hline Solvent & Relative Activity $(\%)$ \\
\hline Hexane & 94 \\
Ethanol & $27^{\mathrm{a}}$ \\
Methanol & $0.75^{\mathrm{a}}$ \\
Acetone & $25^{\mathrm{a}}$ \\
Buffer $(7.0,50 \mathrm{mmol} / \mathrm{L})$ & 100 \\
\hline
\end{tabular}

a differ significativelly $-\mathrm{p}=0.095$

Ciênc. agrotec., Lavras, v. 30, n. 3, p. 494-502, maio/jun., 2006 


\section{CONCLUSION}

The Rhizopus sp. lipase could be purified to SDSPAGE homogenity, although the lipolytic fraction seemed to contain two lipase isoforms. This fraction was purified 9.7-fold, and presented $0.25 \%$ yield. The lipase studied showed a high optimum temperature and also good stability in hydrophobic solvents which makes it a good candidate for esterification reactions in organic media. Among the substrates tested the enzyme showed better activity against short to medium chain fatty acids, suggesting that future catalysis assays should be conducted applying substrates with $12 \mathrm{C}$ or less carbon chains.

\section{ACKNOWLEDGMENTS}

This work was supported by CAPES.

\section{REFERENCES}

BEISSON, F.; TISS, A.; RIVIÈRE, C.; VERGER, R. Methods for lipase detection cnd assay: a critical review. European Journal of Lipid Science and Technology, Winheim, p. 133-153, 2000.

D'ANNIBALE, A.; SERMANNI, G. G.; FREDERICI, F.; PETRUCCIOLI, M. Olive-mill wastewaters: a promissing substrate for microbial lipase production. Bioresource Technology. Available at: $\leq$ www. sciencedirect.com Access at: 20 Jan. 2005.

GANDHI, N. N.; PATIL, N. S.; SWANT, S. B.; JOSHI, J. B. Lipase-catalysed esterification. Catalysis Reviews Science Engineers, [S.1.], v. 42, n. 4, p. 439-480, 2000.

GAO, Y.; BREUIL, C. Properties and substrate specificities of an extracellular lipase purified from Ophistoma piceae. World Journal of Microbiology and Biotechnology, Oxford, v. 14, p. 421-429, 1998.

HIOL, A.; JONZO, M. D.; DRUET, D.; COMEAU, L. C. Production, purification and characterization of an extra cellular lipase from Mucor hiemalis f. hiemalis. Enzyme and Microbial Technology, [S.1.], v. 25, p. 80-87, 1999.

HIOL, A.; JONZO, M. D.; RUGANI, N.; DRUET, D.; SARDA, L.; COMEAU, L. C. Purification and characterization of an extra cellular lipase from a thermophilic Rhizopus oryzae strain isolated from palm fruit. Enzyme and Microbial Technology, [S.1.], v. 26, p. 421-430, 2000.
JAEGER, K. E.; EGGERT, T. Lipases for biotechnology. Current Opinion in Biotechnology, Oxford, v. 13, p. 390397, 2002.

KAMBOUROVA, M.; KIRILOVA, N.; MANDEVA, R.; DEREKOVA, A. Purification and properties of thermostable lipase from a thermophilic Bacillus stearothermophilus MC7. Journal of Molecular Catalysis B: Enzymatic, [S.1.], v. 22, p. 307-313, 2003.

KERMASHA, S.; SAFARI, M.; BISAKOWSKI, B. Characterization of purified lipase fractions from Rhizopus niveus. Journal of Agriculture and Food Chemistry, Easton, v. 46, p. 4451-4456, 1998.

KIRK, O.; BORCHERT, T. V.; FUGLSANG, C. C. Industrial enzyme applications. Current Opinion in Biotechnology, Oxford, v. 13, p. 345-351, 2002.

LAEMMLI, U. K. Cleavage of structural proteins during the assembly of the head of bacteriophage T4. Nature, London, v. 227, p. 680-685, 1970.

LIN, S. F.; CHIOU, C. M.; TSAI, C. Y. Effect of Triton X-100 on alkaline lipase production by Pseudomonas pseudoalcaligenes F-111. Biotechnology letters, [S.1.], v. 17, n. 9, p. 959-962, 1995.

LOWRY, O. H.; ROSEBROUGH, N. J.; FARR, A. L.; RANDALL, R. J. Protein measurement with the phenol folin reagent. Journal of Biological Chemistry, Baltimore, v. 193, p. 265-275, 1951.

MACEDO, G. A.; PASTORE, G. M.; RODRIGUES, M. I. Optimising the synthesis of isoamyl butyrate using Rhizopus sp. lipase with a central composite rotatable design. Process Biochemistry, [S.1.], v. 39, p. 687-692, 2004.

MACEDO, G. M.; SOBERÓN-LOZANO, M. M.; PASTORE, G. M. Enzymatic synthesis of short chain citronellyl esters by a new lipase from Rhizopus sp. Eletronic Journal of Biotecnology, [S.1.], v. 6, n. 1, p. 72-75, 2003.

MELLO, M. M. L. L.; PASTORE, G. M.; MACEDO, G. A. Optimized synthesis of citronellyl flavor esters using free and immobilized lipase from Rhizopus sp. Process Biochemistry, [S.1.], v. 40, p. 3181-3185, 2005. 
MOZAFFAR, Z.; WEETE, J. D. Purification and properties of an extracellular lipase from Phytium ultimum. Lipids, Champaign, v. 31, p. 379-384, 1993.

NAMBOODIRI, V. M. H.; CHATTOPADHYAYA, R. Purification and characterization of a novel thermostable lipase from Aspergillus niger. Lipids, Champaign, v. 35, $\mathrm{n}$. 5, p. 495-502, 2000.

PALEKAR, A. A.; VASUDEVAN, P. T.; YAN, S. Purification of lipase: a review. Biocatalysis Biotransformation, [S.1.], v. 18 , p. $177-200,2000$.

PARK, E. Y.; PIZARRO, A. V. L. Lipase-catalysed production of biodiesel fuel from vegetable oils contained in waste activated bleaching earth. Process Biochemistry, [S.1.], v. 38, p. 1077-1082, 2003.

RAZAK, C. N. A.; SALLEH, A. B.; MUSANI, R.; SAMAD, M. Y.; BASRI, M. Some characterisitics of lipases from thermophilic fungi isolated from palm oil mill effluent. Journal of Molecular Catalysis B: Enzymatic, [S.l.], v. 3, p. 153-159, 1997.

SAXENA, R. K.; DAVIDSON, W. S.; SHEORAN, A.; GIRI, B. Purification and characterization of an alkaline thermostable lipase from Aspergillus carneus. Process Biochemistry, [S.1.], v. 39, p. 239-247, 2003.

TAN, T.; ZHANG, M.; XU, J.; ZHANG, J. Optimization of culture conditions and properties of lipase from Penicillium camembertii Thom PG-3. Process Biochemistry, v. 39, p. 1495-1502, 2004.

VOET, D.; VOET, J. G. Biochemistry. New York: J. Wiley \& Sons, 1995. $1361 \mathrm{p}$.

YANG, X.; WANG, B.; CUI, F.; TAN, T. Production of lipase by repeated batch fermentation with immobilized Rhizopus arrhizus. Process Biochemistry, [S.I.], v. 40, p. 2095-2103, 2005.

Ciênc. agrotec., Lavras, v. 30, n. 3, p. 494-502, maio/jun., 2006 